\title{
Analisis kesalahan siswa berdasarkan tahapan Newman pada materi aritmatika sosial
}

\author{
Ryanti Nur Ika Puspaningrum1, Euis Eti Rohaeti² dan Rippi Maya3 \\ Prodi Pendidikan MatematikaFPMS, IKIP Siliwangi Cimahi \\ ryanti@student.ikipsiliwangi.ac.id
}

Received: 30 April 2020;Accepted: 15 Mei 2020; Published: 20 Juni 2020

\begin{abstract}
Abstrak
Tujuan penelitian ini adalah untuk menganalisis kesalahan siswa SMP dalam menyelesaikan soal Aritmatika Sosial, dengan jumlah subjek 37 siswa kelas VII. Penelitian ini merupakan penelitian deskriptif kualitatif. Instrumen tesnya berupa soal uraian (esai) yang berjumlah lima soal. Berdasarkan hasil penelitian, persentase rata-rata siswa melakukan kesalahan pada tahap membaca soal sebesar o\%, memahami masalah sebesar 23,2\%, transformasi masalah sebesar 28,6\%, pada keterampilan proses sebesar 44,9\%, dan penulisan jawaban akhir sebesar 78,4\%. Dari hasil analisis diperoleh bahwa siswa melakukan empat jenis kesalahan yaitu: Kesalahan dalam penulisan satuan uang; Kesalahan dalam menuliskan unsur yang diketahui dan ditanyakan; Kesalahan dalam menggunakan rumus; dan Kesalahan dalam penarikan kesimpulan.
\end{abstract}

Kata kunci: Aritmatika Sosial, Tahapan Newman

\begin{abstract}
This study aims to analyze the errors in solving problems on Social Arithmetics material. This is a qualitative descriptive study. The research subjects are 37 students of junior high school in grade VII. The test instrument is in the form of five essays. The results showed that the average percentage of students that made mistakes in the problem reading stage was $O \%$, in understanding the problem was $23.2 \%$, in problem transformation was $28.6 \%$, in process skills $44.9 \%$, and in writing the final answer was $78.4 \%$. Analysis results found that there are four types of errors made by students, namely Errors in writing units of money; Errors in writing elements that are known and asked; Errors in using formulas; and Errors in withdrawals conclusion.
\end{abstract}

Keywords: Social Arithmetic, Newman Stage 
Ryanti Nur Ika Puspaningrum, Rippi Maya, Euis Eti Rohaeti

\section{PENDAHULUAN}

Pendidikan matematika mempunyai kontribusi terhadap berkembangnya ilmu pendidikan. Fitriatien (Nurhayati, 2020) menyatakan bahwa ilmu yang membantu dalam mengembangkan pendidikan yaitu matematika. Oleh karena itu, peran pendidikan matematika sangat penting karena matematika adalah ratunya ilmu, sehingga menjadi dasar dalam berbagai bidang pendidikan. Menurut Susanto (Fitriatien, 2019) bahwa matematika merupakan salah satu disiplin ilmu yang dapat meningkatkan kemampuan berpikir dan berargumentasi, memberikan kontribusi dalam penyelesaian masalah sehari-hari dan dalam dunia kerja, serta memberikan dukungan dalam pengembangan ilmu pengetahuan dan teknologi. Salah satu kemampuan yang sangat penting untuk dikuasai dalam soal matematika yaitu penguasaan kemampuan menyelesaikan soal cerita yang berhubungan dengan kehidupan sehari-hari.

Dalam keseharian kita, sering kali secara tidak sadar kita menjumpai keterkaitan antara materi pembelajaran dalam kelas dengan kehidupan nyata. Rohaeti (2011) menyatakan, "Matematika yang diajarkan di sekolah diharapkan tidak lepas dari kehidupan keseharian siswa”. Materi matematika yang berkaitan dengan kehidupan sehari-hari salah satunya adalah arimatika sosial. Aritmatika sosial sering dijumpai dalam penjualan, pembelian, keuntungan, kerugian, bunga, pajak, bruto, neto, dan tara.

Kenyataannya, siswa masih sering melakukan kesalahan dalam menyelesaikan soal aritmatika sosial. Hal ini sejalan dengan penelitian Nurhayati (2020) yang menyatakan bahwa hasil belajar siswa terhadap materi aritmatika sosial masih rendah. Untuk mengetahui kesalahan siswa dalam menyelesaikan soal, salah satunya dengan menggunakan tahapan Newman. Menurut Singh (Magfirah, 2019) dalam menyelesaikan soal uraian, Newman menyarankan lima tahapan pengerjaanya itu tahapan: membaca, (2) memahami makna suatu permasalahan, (3) transformasi, (4) keterampilan proses, dan (5) penulisan jawaban. Dengan tahapan ini, dapat ditemukan penyebab terjadinya kesalahan siswa.

Berdasarkan uraian di atas maka penulis merasa perlu menggunakan tahapan Newman untuk menganalisis kesalahan siswa dalam menyelesaikan soal Aritmetika Sosial.

\section{METODE}

Studi ini merupakan jenis penelitian deskriptif kualitatif yang dilaksanakan pada semester genap tahun ajaran 2019/2020. Subjek penelitiannya adalah 37 orang siswa kelas VII. Teknik analisis data menggunakan tahapan Newman, sedangkan pengumpulan datanya dengan menggunakan instrumen tes, yang meliputi lima soal uraian. Soal uraian tersebut dijabarkan sebagai berikut:

1. Toko Medisa menjual berbagai alat tulis. $\mathrm{Bu}$ Rani membeli beberapa jenis pulpen di toko tersebut.

- Pulpen A dibeli seharga Rp 8.00o/buah dan mendapatkan untung $\mathrm{Rp}$ 500/buah.

- Pulpen B dijual seharga Rp 11.00o/buah tetapi rugi Rp 1.500/buah.

- Pulpen C dibeli seharga Rp 15.000/lusin dan dijual seharga $\mathrm{Rp}$ $1.500 /$ buah.

- Pulpen D dibeli seharga Rp 72.000/lusin dan dijual sehargaRp $5.500 /$ buah.

Buatlah tabel harga beli, jual, untung dan rugi dari permasalahan diatas dan lengkapilah tabel tersebut.

2. Toko Subur Abadi menjual beberapa jenis beras.

- Beras A mempunyai bruto $50 \mathrm{~kg}$ dan tara $2 \mathrm{~kg}$.

- Beras B mempunyai bruto 46 kg dan netto $44 \mathrm{~kg}$.

- Beras C memiliki tara $23 \mathrm{~kg}$ dan netto $20 \mathrm{~kg}$.

Jurnal Analisa 6 (1) (2020)

47-55 
- Beras D memiliki bruto $21 \mathrm{~kg}$ dan netto $14 \mathrm{~kg}$.

Buatlah tabel bruto, tara dan netto dari permasalahan diatas dan lengkapilah tabel tersebut!

3. Menjelang Tahun Baru, Toko Sejahtera memberi diskon 15\% untuk seluruh barang. Bibi datang ke toko tersebut untuk belanja $3 \mathrm{~kg}$ gula pasir seharga Rp 12.500 per kg dan 4 susu kaleng seharga Rp 9.500 per kaleng. Berapakah total belanjaan Bibi setelah mendapat diskon?

4. Sebuah perusahaan percetakan mencetak sebanyak 7.500 buku yang akan dijual dalam suatu pameran dengan harga Rp 40.000 per buku. Honorarium pengarang 10\% dan pajak yang harus dibayar oleh pengarang $15 \%$. Berapakah besar honorarium bersih yang diterima pengarang?

5. Pak Hendri menyimpan uang di sebuah Bank. Setelah 5 bulan, jumlah seluruh tabungannya menjadi Rp 352.000. Jika Bank memberikan suku bunga 24\% per tahun, berapa simpanan Pak Hendri mulamula?

\section{HASIL DAN PEMBAHASAN}

Penelitian ini membahas tentang analisis kesalahan siswa dalam mengerjakan soal Aritmatika Sosial. Data hasil tes tertulis siswa, kemudian dianalisis kesalahannya dengan menggunakan tahapan Newman. Berikut disajikan teknik analisis data yang digunakan menurut Fitriatien (2019).

Tabel 1. Teknik Analisis Data Berdasarkan Prosedur Newman

\begin{tabular}{|c|c|c|}
\hline No. & Jenis Kesalahan & $\begin{array}{c}\text { Kode } \\
\text { Kesalahan }\end{array}$ \\
\hline 1. & $\begin{array}{l}\text { Membaca (reading) } \\
\text { Indikator: } \\
\text { Siswa tidak mampu memaknai kata dari kalimat atau istilah yang } \\
\text { sulit dalam soal cerita. }\end{array}$ & $\mathrm{T} 1$ \\
\hline 2. & $\begin{array}{l}\text { Memahami masalah (comprehension) } \\
\text { Indikator: } \\
\text { Siswa tidak mampu menemukan apa saja yang diketahui serta } \\
\text { yang ditanyakan dalam soal cerita. }\end{array}$ & $\mathrm{T} 2$ \\
\hline 3. & $\begin{array}{l}\text { Transformasi masalah (transformation) } \\
\text { Indikator: } \\
\text { Siswa tidak mengetahui operasi apa yang digunakan dalam } \\
\text { menyelesaikan soal cerita tersebut, meskipun siswa mengetahui } \\
\text { apa yang diketahui dan ditanyakan soal. }\end{array}$ & $\mathrm{T}_{3}$ \\
\hline 4. & $\begin{array}{l}\text { Keterampilan proses (process skills) } \\
\text { Indikator: } \\
\text { Prosedur yang dibutuhkan untuk menyelesaikan operasi secara } \\
\text { tepat tidak diketahui siswa. }\end{array}$ & $\mathrm{T}_{4}$ \\
\hline 5 . & $\begin{array}{l}\text { Penulisan jawaban akhir (encoding) } \\
\text { Indikator: } \\
\text { Siswa tetapi tidak mampu menyimpulkan penyelesaian kedalam } \\
\text { kalimat matematika, meskipun siswa mampu dengan tepat } \\
\text { menyelesaikan soalnya. }\end{array}$ & $\mathrm{T}_{5}$ \\
\hline
\end{tabular}

Setelah dianalisis dan dikelompokkan

kesalahan yang dilakukan siswa, peneliti 
Ryanti Nur Ika Puspaningrum, Rippi Maya, Euis Eti Rohaeti

menyajikan hasil dalam bentuk tabel untuk kesalahan yang dilakukan siswa: setiap nomor soal. Berikut disajikan tabel jenis

Tabel 2. Hasil Kesalahan yang Dilakukan Siswa

\begin{tabular}{|c|c|c|c|c|c|c|c|}
\hline \multirow[t]{2}{*}{ No } & \multirow[t]{2}{*}{ Kategori } & \multicolumn{5}{|c|}{$\begin{array}{c}\text { Persentase Kesalahan Siswa pada } \\
\text { Tiap Nomor Soal }(\%)\end{array}$} & \multirow{2}{*}{$\begin{array}{c}\text { Rata-rata } \\
\text { Kesalahan } \\
(\%)\end{array}$} \\
\hline & & 1 & 2 & 3 & 4 & 5 & \\
\hline 1. & Tahap Membaca & 0 & 0 & 0 & 0 & 0 & 0 \\
\hline 2. & $\begin{array}{l}\text { Tahap Memahami } \\
\text { Masalah }\end{array}$ & 29,7 & 27,0 & 18,9 & 18,9 & 21,6 & 23,2 \\
\hline 3. & $\begin{array}{l}\text { Tahap Transformasi } \\
\text { Masalah }\end{array}$ & 40,5 & 35,1 & 21,6 & 18,9 & 27,0 & 28,6 \\
\hline 4. & $\begin{array}{l}\text { Tahap Keterampilan } \\
\text { Proses }\end{array}$ & 89,2 & 89,2 & 10,8 & 16,2 & 18,9 & 44,9 \\
\hline 5. & $\begin{array}{l}\text { Tahap Penulisan } \\
\text { Jawaban Akhir }\end{array}$ & 94,6 & 97,3 & 59,5 & 75,7 & 64,9 & 78,4 \\
\hline
\end{tabular}

Keterangan :

1. Persentase diperoleh dari jumlah salah satu setiap kategori dibagi jumlah seluruh siswa.

2. Data yang dianalisis sebanyak tiga siswa dari 37 siswa.

Dari Tabel 2 terlihat bahwa secara keseluruhan, tidak terdapat kesalahan membaca di tahap satu dari kelima soal yang dianalisis. Pada tahap dua sampai lima, masih terdapat kesalahan. Kesalahan terbesar dilakukan pada tahap lima, yaitu tahap penulisan jawaban akhir, sementara kesalahan terkecil pada tahap dua, yaitu pada tahap memahami masalah.

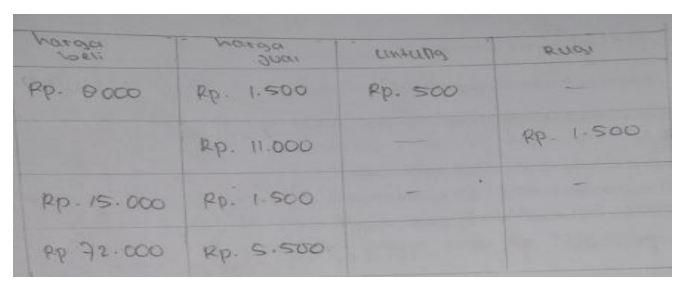

Gambar 1. Hasil Pekerjaan S-1 pada Soal Satu
Pada Gambar 1 terlihat bahwa siswa dengan kode S-1 yang mengalami kesalahan ditahap memahami masalah. Pada soal nomor satu langsung menjawab soal tersebut tanpa menuliskan unsur yang diketahui dan ditanyakan. Ini terjadi karena siswa tidak terbiasa menyelesaikan masalah dalam bentuk soal cerita. Sehingga S-1 ini mengalami kesalahan pada tahap keterampilan proses, dan tahap penulisan jawaban akhir. Kesalahan ini terjadi karena S-1 langsung menuliskan jawabannya tanpa menghitung dan menuliskan rumus yang dipakai dalam menyelesaikan soal. 


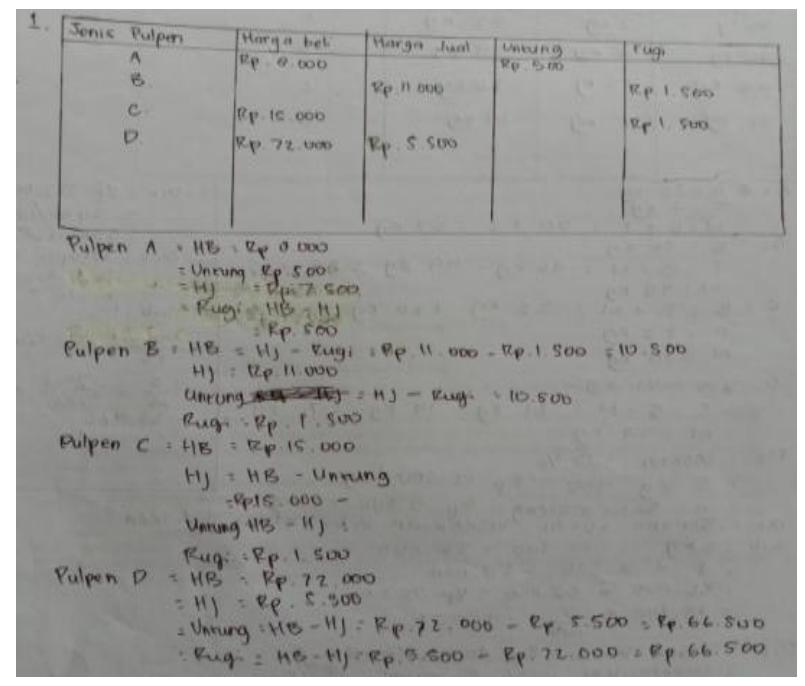

Gambar 2. Hasil Pekerjaan S-2 pada Soal Satu

Pada Gambar 2, siswa S-2 sudah mampu menuliskan unsur yang diketahui dan ditanyakan dari soal, S-2 melakukan proses menghitung sesuai dengan temuan dari soal tersebut. Akan tetapi S-2 mengalami ketidaktelitian dalam menuliskan satuan uang, tidak teliti dalam memahami maksud soal, dan tidak menuliskan kesimpulannya.

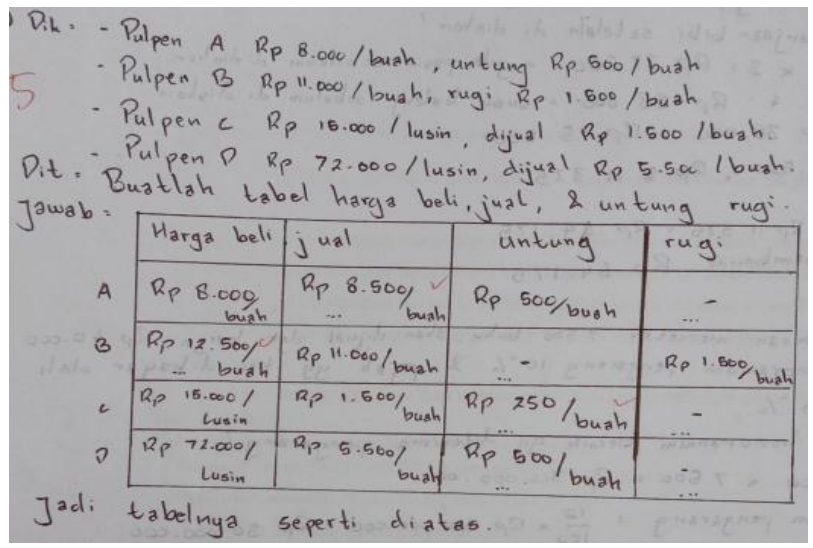

\section{Gambar 3. Hasil Pekerjaan S-3 pada Soal Satu}

Pada Gambar 3, siswa S-3 sudah memahami maksud soal, menuliskan unsur yang diketahui dan ditanyakan, menuliskan satuan uang, dan membuat kesimpulan. Namun, tidak menuliskan proses menghitung untuk mendapatkan hasil serta tidak menggunakan rumus yang dipakai untuk menyelesaikan masalah tersebut. Hal ini disebabkan karena siswa terburu-buru dalam menyelesaikan soal, yang sejalan dengan penelitian Fatahillah (2017).

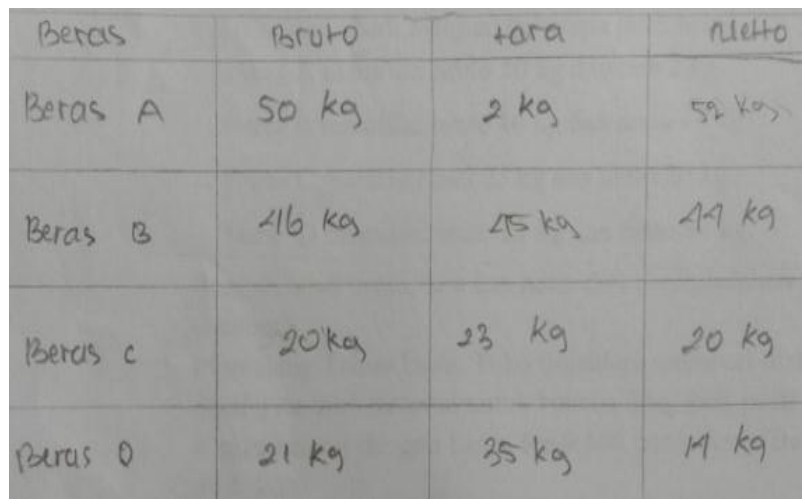

\section{Gambar 4. Hasil Pekerjaan S-1 pada Soal Dua}

Pada soal nomor dua, S-1 melakukan kesalahan yang sama dengan soal satu. Siswa langsung menjawab tanpa menuliskan unsur yang diketahui dan ditanyakan, tidak menghitung, dan tidak memberikan kesimpulan. Tetapi S-1 menuliskan satuan berat pada tiap beras.

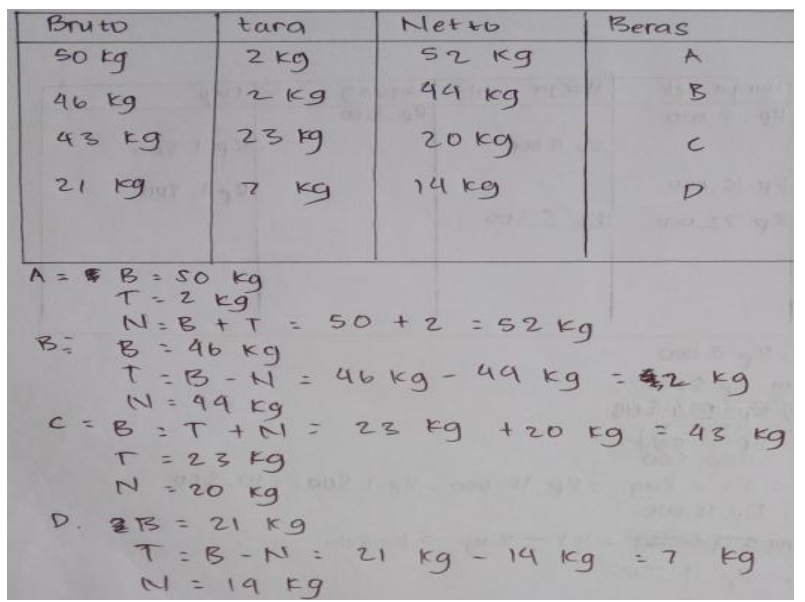

\section{Gambar 5. Hasil Pekerjaan S-2 pada Soal} Dua

Pada Gambar 5 terlihat bahwa S-2 pada soal dua melakukan kesalahan yang sama dengan soal satu. 


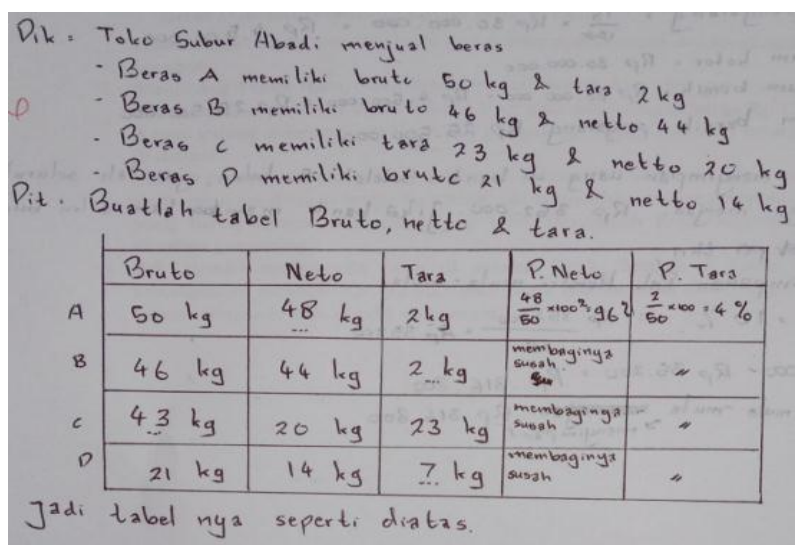

\section{Gambar 6. Hasil Pekerjaan S-3 pada Soal Dua}

Begitu pula dengan Siswa S-3. Pada soal dua, juga melakukan kesalahan yang sama dengan soal satu.

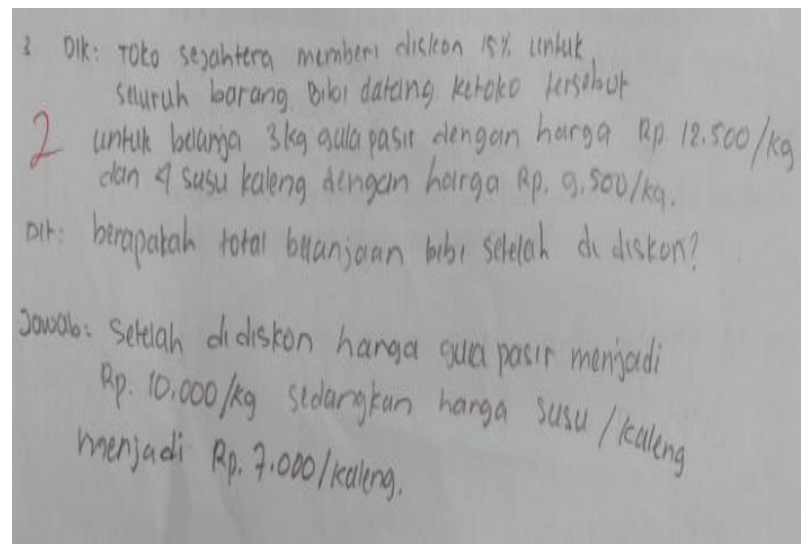

Gambar 7. Hasil Pekerjaan S-1 pada Soal Tiga

Pada soal tiga, S-1 mampu menuliskan unsur yang diketahui dan ditanyakan, tetapi tidak melakukan proses perhitungan dan hanya menuliskan kesimpulan yang salah. Hal ini terjadi karena siswa tidak mengetahui langkah apa yang harus dilakukan dalam menyelesaikan soal tersebut, yang sejalan dengan penelitian Fatahillah (2017).

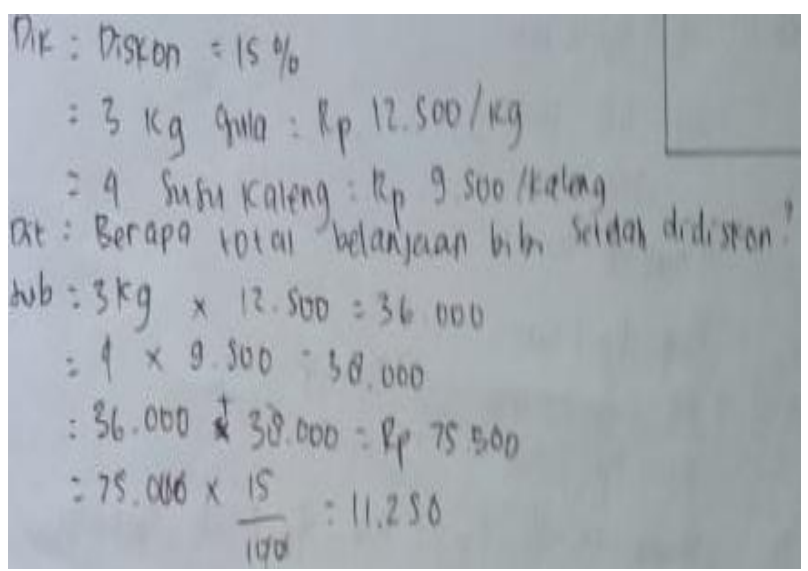

\section{Gambar 8. Hasil Pekerjaan S-2 pada Soal Tiga}

Pada Gambar 8, siswa S-2 pada soal tiga sudah menuliskan unsur yang diketahui dan ditanyakan, melakukan proses menghitung, tetapi tidak menggunakan rumus dan tidak mengurangkan besar diskon yang diperoleh dengan harga keseluruhan. S-2 juga dalam menuliskan satuan uang tidak secara lengkap serta tidak melakukan penarikan kesimpulan.

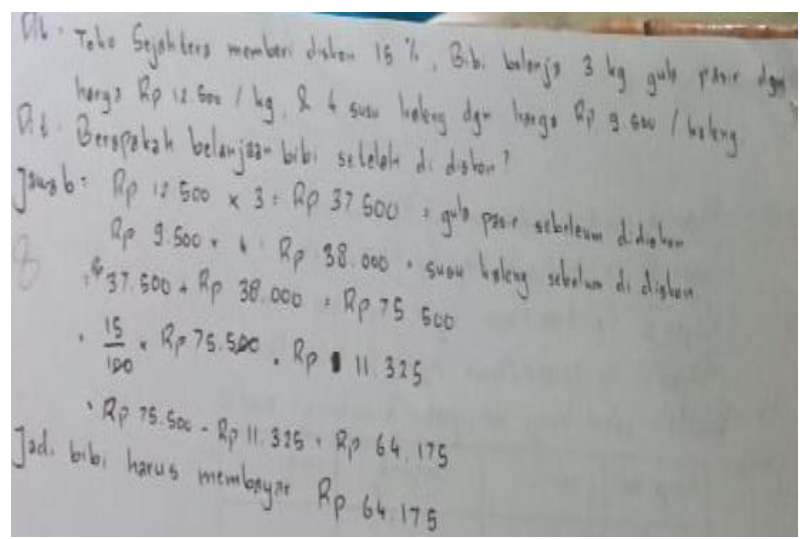

\section{Gambar 9. Hasil Pekerjaan S-3 pada Soal Tiga}

Siswa S-3 sudah mampu menjawab disemua tahapan, hanya saja S-3 ini tidak menggunakan rumus diskon yang telah dipelajarinya. Hal ini disebabkan karena siswa kurang terampil dalam menyelesaikan permasalahan, yang sejalan dengan penelitian Haryati (2016). 


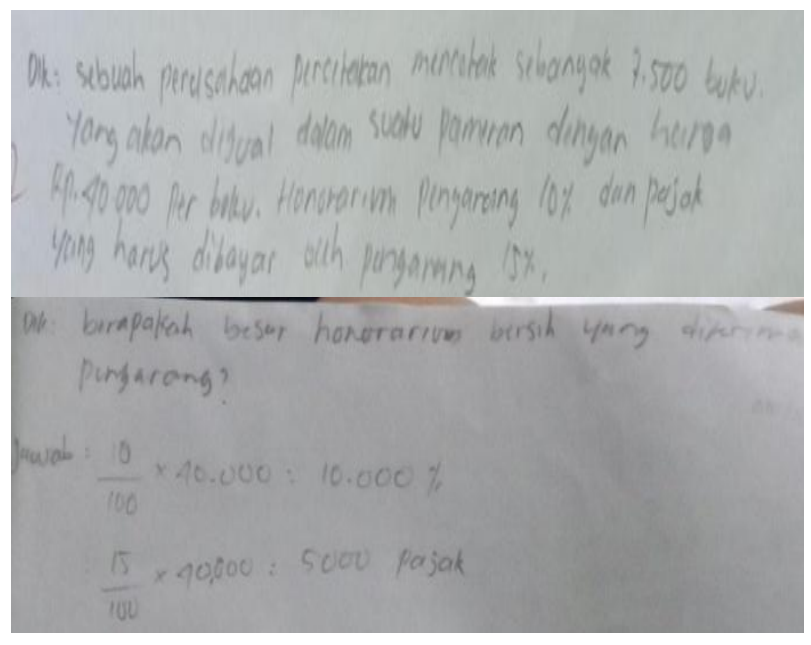

Gambar 10. Hasil Pekerjaan S-1 pada Soal Empat

Selanjutnya pada soal ke empat, siswa S-1 mengalami kesalahan yang sama dengan soal tiga. S-1 melakukan perhitungan, tetapi menghasilkan jawaban yang tidak tepat dan tidak menarik kesimpulannya.

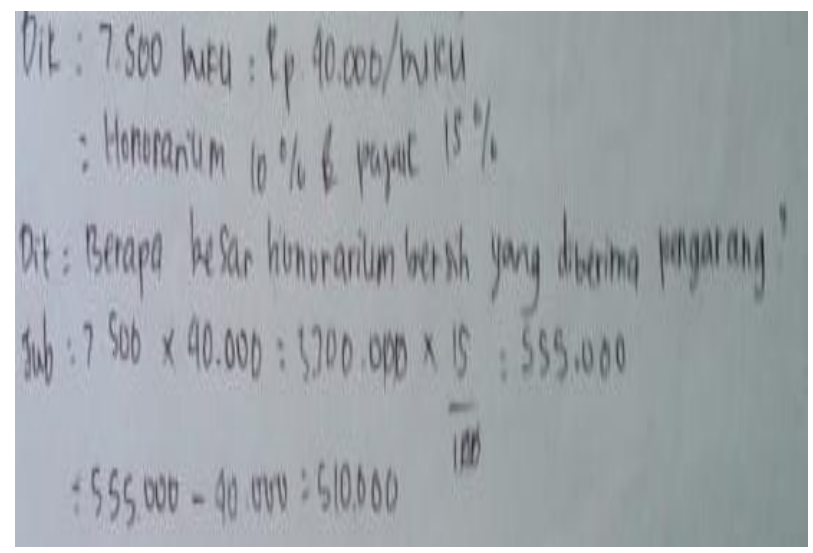

Gambar 11. Hasil Pekerjaan S-2 pada Soal Empat

Sedangkan untuk kesalahan yang dialami siswa S-2 sama dengan soal tiga. Siswa S-2 tidak menggunakan satuan uang dalam menuliskan nominal uang dan tidak menyelesaikan soal dengan tepat. S-2 hanya mengerjakan sesuai yang ia pahami saja.

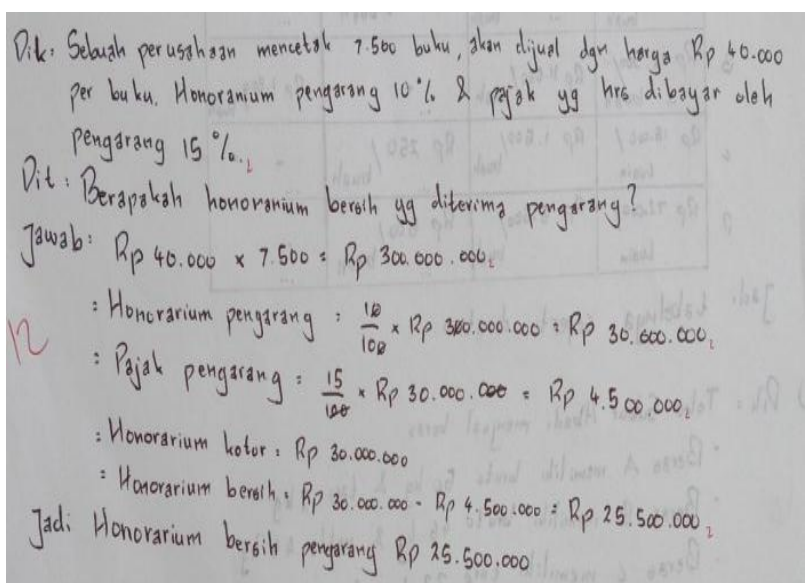

\section{Gambar 12. Hasil Pekerjaan S-3 pada Soal Empat}

Siswa S-3 pada soal ke empat sudah tepat dalam menjawab permasalahan, menuliskan unsur yang diketahui dan ditanyakan, menggunakan satuan uang, melakukan perhitungan dengan memberikan keterangan dari setiap yang dihitung, dan menarik kesimpulan. Hal ini berarti S-3 sudah memahami maksud dari soal.

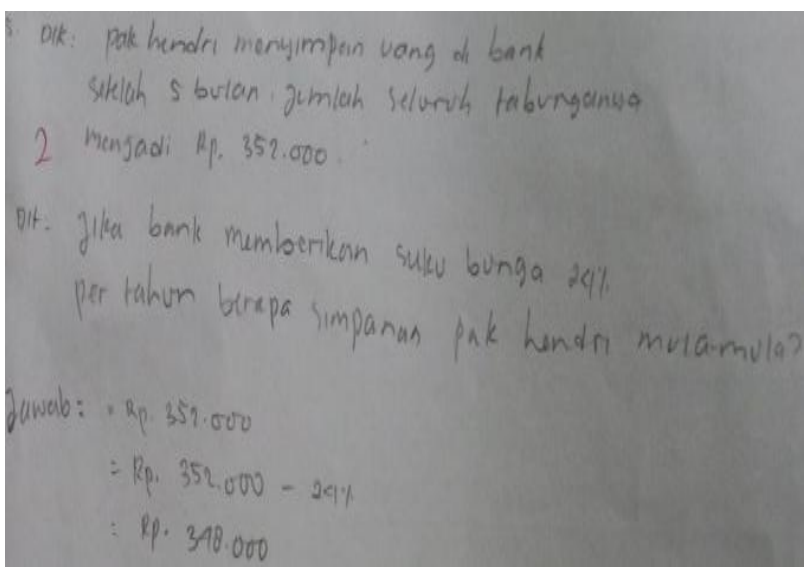

\section{Gambar 13. Hasil Pekerjaan S-1 pada Soal Lima}

Pada soal ke lima, siswa S-1 mengalami kesalahan yang sama dengan soal ke empat, dimana S-1 hanya menuliskan apa yang diketahui dan ditanyakan dari soal dan melakukan perhitungan yang salah, sehingga memberikan jawaban yang kurang tepat. 


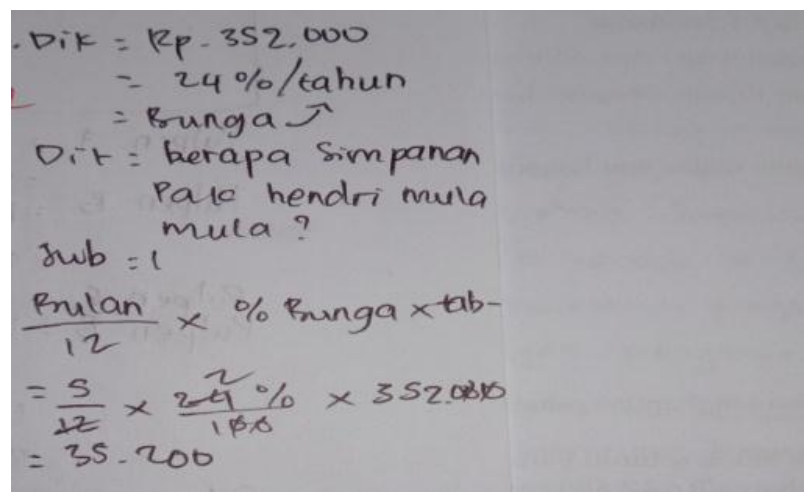

\section{Gambar 14. Hasil Pekerjaan S-2 pada Soal Lima}

Untuk S-2, menuliskan diketahui dan ditanyakan, menggunakan rumus, serta melakukan proses menghitung. Tetapi S-2 ini tidak menggunakan satuan uang dan tidak menuliskan kesimpulannya.

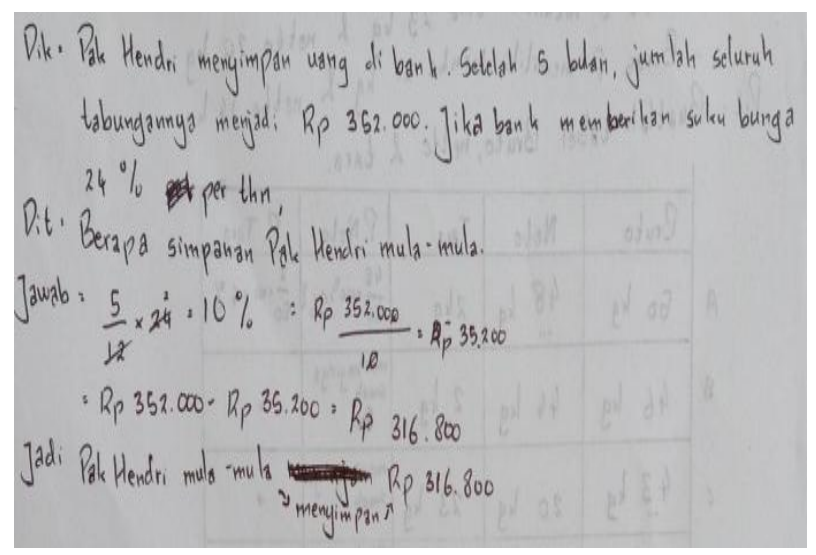

\section{Gambar 15. Hasil Pekerjaan S-3 pada Soal Lima}

Pada jawaban S-3, ia sudah menuliskan diketahui dan ditanyakan, menggunakan satuan uang, melakukan perhitungan, dan menarik kesimpulan. Tetapi S-3 dalam menghitung jawaban kurang tepat sehingga menghasilkan jawaban yang salah serta S-3 tidak menggunakan rumus dalam menyelesaikan soal tersebut.

Kesalahan siswa pada tiap tahap dari semua soal yaitu pada tahap membaca sebesar o\%, tahap memahami masalah sebesar $23,2 \%$, tahap transformasi masalah 28,6\%, tahap keterampilan proses $44,9 \%$ dan tahap penulisan jawaban akhir sebesar 78,4\%.

\section{KESIMPULAN}

Berdasarkan analisis data yang telah dilakukan dapat disimpulkan bahwa siswa melakukan kesalahan pada materi aritmatika sosial disebabkan karena (1) Kesalahan dalam penulisan satuan uang, (2) Kesalahan dalam menuliskan unsur yang diketahui dan ditanyakan, (3) Kesalahan dalam menggunakan rumus, dan (4) Kesalahan dalam penarikan kesimpulan. Adapun saran yang dapat diberikan oleh penulis yaitu: (1) Siswa lebih teliti dalam memahami maksud soal, (2) Siswa diberikan penjelasan bahwa dalam menuliskan uang haruslah ada satuannya agar lebih jelas antara besar uang dan bilangan, dan (3) Penggunaan rumus berpengaruh terhadap jawaban.

\section{UCAPAN TERIMA KASIH}

Penulis mengucapkan banyak terima kasih kepada Kepala Sekolah dan guru mata pelajaran matematika SMPN 9 Cimahi yang telah mengizinkan penulis untuk melaksanakan observasi di sekolah tersebut. Terima kasih banyak kepada semua pihak yang telah terlibat dan turut mendukung dalam pembuatan artikel. Semoga artikel ini dapat bermanfaat bagi semua pihak.

\section{DAFTAR PUSTAKA}

Fatahillah, A., Wati, Y. F., \& Susanto, S. (2017). Analisis Kesalahan Siswa dalam Menyelesaikan Soal Cerita Matematika Berdasarkan Tahapan Newman beserta Bentuk Scaffolding yang Diberikan.Kadikma,8(1), 40-51.

Fitriatien, S. R. (2019).Analisis Kesalahan dalam Menyelesaikan Soal Cerita Matematika Berdasarkan Newman. 
Jurnal Ilmiah Pendidikan Matematika, 4(1), 53-56.

Haryati, T., Suyitno, A., \& Junaedi, I. (2016). Analisis Kesalahan Siswa SMP Kelas VII dalam Menyelesaikan Soal Cerita Pemecahan Masalah Berdasarkan Prosedur Newman.Unnesa Journal of Mathematics Education, 5(1), 8-15.

Nurhayati, A. S., \& Zanthy, L. S. (2020). Analisis Kesalahan Siswa SMP dalam
Menyelesaikan Soal pada Materi Aritmatika Sosial.APOTEMA: Jurnal Program Studi Pendidikan Matematika, 6(1), 54-66.

Rohaeti, E. E. (2011).Transformasi Budaya Melalui Pembelajaran Matematika Bermakna di Sekolah.Jurnal Pengajaran MIPA,16(1), 139-147. 